\title{
Working
}

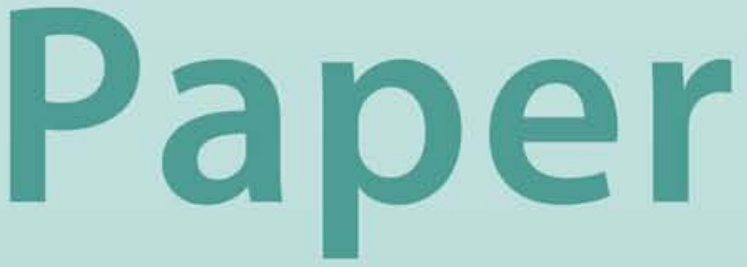




\section{International Capital Crunches: The Time-Varying Role of Informational Asymmetries}

Ashoka Mody and Mark P. Taylor 


\title{
IMF Working Paper
}

\author{
Research Department \\ International Capital Crunches: \\ The Time-Varying Role of Informational Asymmetries
}

Prepared by Ashoka Mody and Mark P. Taylor ${ }^{1}$

February 2002

\begin{abstract}
The views expressed in this Working Paper are those of the author(s) and do not necessarily represent those of the IMF or IMF policy. Working Papers describe research in progress by the author(s) and are published to elicit comments and to further debate.
\end{abstract}

We examine the determinants of capital flows to four developing countries during the 1990s using an explicitly disequilibrium econometric framework in which the supply and demand for capital are not necessarily equal and the actual amount of the flow is determined by the 'short side' of the market. We are thus able to detect instances of 'international capital crunch'一where capital flows are curtailed because of supply-side rationing - and to relate these instances to movements in the underlying fundamentals. The analysis highlights the role of asymmetric information-as distinct from the traditional concern with default risk-in conditioning capital flows.

JEL Classification Numbers: F320, F340, O190

Keywords: Capital flows, disequilibrium, rationing, asymmetric information

Authors’ E-Mail Addresses: amody@imf.org; mark.taylor@warwick.ac.uk

${ }^{1}$ Ashoka Mody is in the Research Department of the International Monetary. Mark Taylor is a professor of economics at University of Warwick and a research fellow, Centre for Economic Policy Research. The research reported in this paper reflects work done while Mark Taylor was a Visiting Scholar in the Research Department of the International Monetary Fund. The World Bank's Research Committee also financed a part of the research. The authors are grateful to Michael Bleaney, Robin Brooks, Olivier Jeanne, Paul Masson, and Antonio Spilimbergo for their comments. However, they remain responsible both for the views expressed in the paper and for any errors which may remain. 


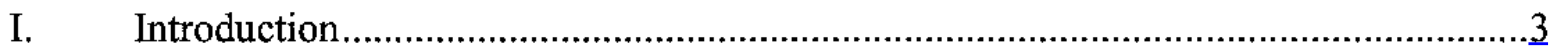

II. Capital Rationing: The Role of Asymmetric Information .........................................

III. Modeling Disequilibrium in Capital Flows: Econometric Issues ..............................

IV. Empirical Implementation .........................................................................10

V. Empirical Results: The Probability of Crunch..................................................12

A. Estimates of Supply and Demand Functions ...........................................12

B. Probability of a Capital Crunch.................................................................15

C. Domestic Factors Associated with a Capital Crunch .....................................16

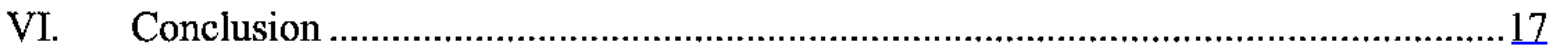

Table 1. Estimated Supply and Demand Functions for International Capital Flows.............14

Figures:

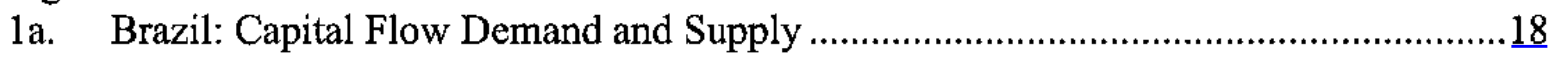

1b. Brazil: Probability of Crunch................................................................................18

1c. Brazil: Reserves/Imports and Reserves/Short-Term Debt .......................................18

2a. Mexico: Capital Flow Demand and Supply ........................................................19

2b. Mexico: Probability of Crunch ...............................................................................

2c. Mexico: Reserves/Imports and Reserves/Short-Term Debt .....................................19

3a. Korea: Capital Flow Demand and Supply ...........................................................20

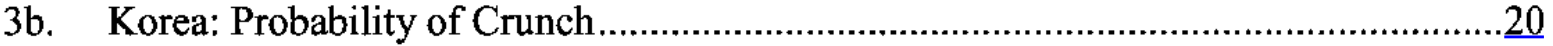

3c. Korea: Reserves/Imports and Reserves/Short-Term Debt.......................................20

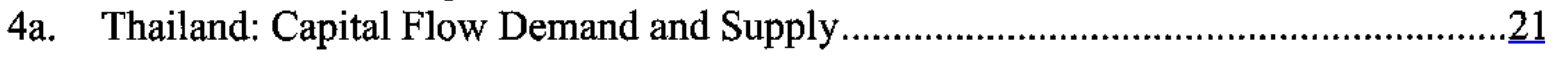

4b. Thailand: Probability of Crunch .......................................................................21

4c. Thailand: Reserves/Imports and Reserves/Short-Term Debt ......................................21

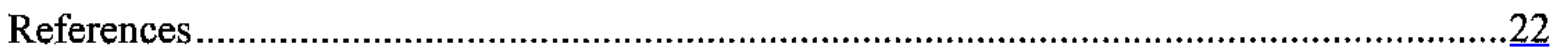




\section{INTRODUCTION}

The principal purpose of this paper is to estimate developing country supply and demand functions for international capital, allowing for the possibility of market disequilibrium. We believe this creates a more analytical foundation for studying the determinants of international capital flows compared to the prevalent approach that seeks to identify so-called 'push' and 'pull' factors. In particular, the analysis highlights the critical role of asymmetric information - as distinct from the traditional concern with default risk-in conditioning capital flows. The effects of asymmetric information are observed at various time horizons.

Analysis of short-term fluctuations and long-term prospects of capital flows to developing countries remains of continuing interest to international financial economists and to policymakers. For recent analyses and surveys, see e.g. Calvo, Leiderman, and Reinhart (1996), World Bank (1997), Reinhart and Reinhart (1998), International Monetary Fund (2000), Woo, Sachs, and Schwab (2000), and Agénor and Montiel (1999). Following resurgence in international capital flows to developing countries during the first half of the $1990 \mathrm{~s}$, the second half of the decade was characterized by significant turbulence, including periods of considerable optimism or 'exuberance' as well as significant financial crises in Latin America, East Asia, Russia and elsewhere. There is some presumption, therefore, that the supply and demand for capital may not be in 'equilibrium.' The supply of capital may be rationed-i.e., a number of developing countries would be willing to acquire more international capital at the prevailing cost of capital. While some countries may be more permanently constrained, many may be heavily rationed during periods of crisis. It is possible also that supply may exceed demand when international investors exhibit a high degree of exuberance.

In this paper we seek to make three contributions. First, for four important emerging market economies, we attempt to distinguish between factors that determine the supply of international capital and those that determine the demand for such capital. Second, using those estimated functions, we proceed to identify whether, and when, countries have been capital constrained or, alternatively, have had access to an excess supply of capital. Finally, we argue, based on the results obtained, that the supply of capital flows to developing countries is influenced not only by default risk but also significantly by asymmetric information. The extent and implications of the informational asymmetry vary considerably over time.

Empirically, there are at least three different, but complementary, taxonomies of the underlying forces driving capital flows. Firstly, economists have traditionally tended to analyze capital flows to emerging markets in terms of 'push' and 'pull' factors (see e.g. Chuhan, Claessens, and Mamingi, 1998; Taylor and Sarno, 1997; Agénor, 1998; Mody, Taylor and Kim, 2001a). In this context, country-specific or 'pull' factors are those seen as reflecting domestic investment opportunities and risks, which draw in overseas funds, while global or 'push' factors are held to reflect those influences that direct investment funds from international money centers toward emerging markets. Secondly, researchers have sometimes focused more explicitly on the underlying characteristics of capital flows which 
are not directly observable, in particular their degree of potential reversibility (see e.g. Claessens, Dooley, and Warner, 1995; Sarno and Taylor, 1999a,b; Mody, Taylor, and Kim, 2001b).

Perhaps somewhat curiously, the third potential taxonomy we have identified in this paper is the least investigated but is the closest to standard economic analysis, namely the identification of the supply of, and the demand for, capital flows to developing countries. The most recent of such efforts that we have been able to identify is by Hajivassiliou (1986). Eaton and Gersowitz (1980 and 1981) also use a supply and demand estimation framework but they focus on the stock of publicly held debt to private creditors rather than on the demand and supply of new flows from international markets. Their data is for 1971 and 1974 and is, therefore, essentially an analysis of debt levels in a cross-section of countries. Moreover, the debt levels are explained entirely in terms of domestic variables and global factors play no role. Hajivassiliou's (1986) analysis for 1970-1982 is closer in spirit to that presented in this paper but he does not focus, as we do, on estimating a time-varying measure of the probability of capital crunches and also does not include global factors in his analysis. By pooling the data, Hajivassiliou (1986) imposes homogeneity across countries that he recognizes may not be appropriate.

There are a number of potential reasons why this most basic of economic taxonomiessupply and demand-has proved least popular in the empirical analysis of capital flows. In the now more conventional push-pull analysis, for example, determining whether a factor is global or country-specific is generally straightforward, although determining whether it affects the demand for capital or the supply of capital, or both, may be econometrically more difficult and, in any particular analysis, of less interest to the researcher than gauging its overall impact on capital flows. Moreover, given the strong resurgence in capital flows to developing countries during the early 1990s and the rapid repatriation of much developed country capital in the aftermath of the various emerging market crises of the late 1990s, there is perhaps a belief among many international financial economists that observed capital flows do not necessarily always represent the balance of supply and demand in a clearing market. This, however, is precisely the issue that we wish to address in this paper. In particular, we wish to analyze situations in which the supply of capital flowing to a developing country outstrips the demand and, conversely, where demand for capital inflows outstrips supply and there is capital rationing or a 'capital crunch.'

Models of credit rationing, since the seminal analysis of Stiglitz and Weiss (1981), are, of course, well known. The basic idea is that interest rates may not always be relied upon to clear credit markets because lenders will be wary of lending to high-risk borrowers even if they are offering to pay very high interest rates. There may be an adverse selection problem such that potential borrowers offering to pay very high rates of interest may thereby signal that they are among the least creditworthy. Thus, at some points in time, the demand for credit may outstrip the supply of credit and there will be a 'credit crunch.' Mankiw (1986) discusses the conditions under which the credit market may collapse in such circumstances. Empirical analyses of credit crunches at the domestic level have been carried out by a 
number of authors; see for example Ding, Domac, and Ferri (1998) and-in an explicitly ‘disequilibrium' framework—Ghosh (1999) and Pazarbasioglou (1997).

To our knowledge, however, such an analysis of supply and demand in a disequilibrium framework has not been conducted for the surge and subsequent volatility of international capital flows in the 1990s. In particular, we believe that the analysis presented in this paper is the first attempt to investigate the time-varying dimension of capital crunches faced by emerging markets in response to both global and domestic developments.

We estimate supply and demand functions for capital flows jointly for a country using a maximum likelihood econometric technique. The technique estimates the probability of whether, according to the estimated supply and demand functions, supply is less than demand at any particular point and whether, therefore, there is a capital crunch. Using this methodology, we report estimates of supply and demand functions for capital flows to Brazil, Mexico, Korea and Thailand, over the period 1990-2000, from which we can infer the probability of a capital crunch having occurred at any particular point in time over the sample. Our results are strongly supportive of the postulated model. The estimated probability of capital crunch serves as an index of capital rationing by the market. The movement of this index accords well with underlying economic intuition and knowledge of the recent history of international capital movements. Pulling together the evidence on the determinants of the supply and demand functions and the evidence of credit rationing, we conclude that asymmetric information has a time-varying impact on capital flows to developing countries.

The remainder of the paper is set out as follows. In Section II we discuss various potential underlying causes of capital crunch, while in Section III we set out the econometric issues in estimating a disequilibrium model of capital flows. In section IV we discuss the empirical implementation of the model and the data employed. Our results are reported and discussed in Section V, whilst a final section summarizes and concludes.

\section{Capital Rationing: The Role of Asymmetric Information}

There are three different manifestations of credit rationing in the context of international capital flows. Fundamentally, all three are the result of asymmetric information. However, the consequences of the asymmetry in information materialize at different time horizons.

First, a group of countries may be more or less permanently rationed. In the Stiglitz-Weiss analysis, imperfect information with respect to the creditworthiness of borrowers leads investors to ration the supply of capital rather than supply it to the highest bidder. Although this basic structure provides us with a useful explanation as to why interest rates mav not by themselves be enough to clear the market, it does not help explain the well documented surge in capital flows to developing countries during the early 1990 s and its equally well documented reversal during the various crises of the late 1990s. 
Thus, a second consideration suggests that a reassessment occurs immediately after or around the time of a financial crisis which generates capital rationing or, more dramatically, a 'collapse' in Mankiw's (1986) words or a 'sudden stop' in Calvo and Reinhart's (1999) terms. ${ }^{2}$ Mankiw notes that even if the probability of default does not change, the presence of asymmetric information can cause significant shifts in the supply of credit when conditions change even modestly. Two possibilities exist. Pertinent information may be revealed with respect to the perceived risk and attractiveness of investing in that particular country which may, to a greater or lesser extent, be embodied in changes in the country's credit rating ${ }^{3}$ or in movements in other variables such as the level of foreign reserves in relation to the level of indebtedness. Alternatively, the sudden drying up or reversal of capital flows may simply reflect a herding or contagion effect, as financial crisis in one economy generates the withdrawal of capital from another economy, creating a domino effect (see e.g. Calvo and Reinhart, 1999, Calvo and Mendoza, 2000; Dornbusch, Park, and Claessens, 2000). Thus, supply and demand curves may shift significantly, leading to temporary disequilibrium in international markets. In the empirical work reported below, we model the supply and demand for international capital flows as stable functions of the underlying economic fundamentals. Hence, we are able to explain movements in the probability of capital crunch by relating them to movements in measures of the economic fundamentals. The residuals in our fitted empirical functions may thus to some extent represent pure contagion or herding effects. However, as we shall see, we are in fact able to go a long way towards explaining capital crunches in terms of movements in the underlying fundamentals.

Finally, in between the two extremes of (more or less) permanent credit rationing and episodic rationing reflected in financial crises, one may also distinguish cyclical variations in credit flows that are also the outcome of asymmetric information. Several authors have noted that credit flows are procyclical (see Bernanke, Gertler, and Gilchrist, 1999 for further discussion). Because creditors have imperfect information on borrowers, the premium they charge leads to a preference for the use of cheaper internally generated funds for financing new investments. However, when growth rates increase, the value of the firm's collateral increases, the premium charged for external funds declines, and the extent of external credit increases. This process is labeled the 'financial accelerator' because the cheaper available credit during a period of growth reinforces and accelerates that growth process. However, in a slowdown, the credit slowdown makes the deceleration more rapid.

\footnotetext{
2 Similarly, Caballero and Krishnamurthy (2001) refer to a 'vertical' supply curve for international capital and the lack of substitutability between international and domestic capital.

${ }^{3}$ The evidence presented by Goldstein, Kaminsky, and Reinhart (2000) and Reinhart (2001) suggests that credit ratings are not generally forward-looking.
} 
In our empirical analysis, we find evidence of credit constraints on all three counts, emphasizing the pervasive importance of asymmetric information in determining the supply of capital flows to developing countries.

Previous empirical analyses have also highlighted the significant influence of information asymmetries on international capital transactions. However, these findings are essentially cross-sectional in nature, i.e., informational asymmetry is used to explain differences across countries in the level and composition of flows. Ghosh and Wolf (2000) and Portes and Rey (2001) find that 'gravity' models explain a considerable fraction of bilateral capital flows between countries. Greater distance between two countries implies reduced volume of transactions - and greater distance, Portes and Rey (2001) argue, proxies for asymmetry in information. ${ }^{4}$ In addition, Portes and Rey (2001) find that other variables that measure informational distance, e.g., volume of telephone traffic and the number of branches of multinational banks, also correlate positively with flows. Though their interest is not in capital rationing per se, their conclusion is of interest in the context of this paper. An implication of their finding is that portfolio diversification is not a major objective for international investors. Instead, investors are more likely to invest in countries with business cycles that correlate with cycles in their own countries, a conclusion that is consistent with the results of our paper.

Asymmetric information is consistent with a number of other observed features of international capital flows and sovereign borrowing. Gordon and Bovenberg (1996) identify informational asymmetry as a key factor in explaining the empirical evidence on the limited international mobility of capital. ${ }^{5}$ Gertler and Rogoff (1990) conclude that asymmetric information can especially dampen capital flows to poorer countries because they are not able to offer sufficient credible collateral. Kletzer (1984) also concludes that observed quantity rationing of credit, exclusion of the lowest-income less developed countries from private capital markets, and short-debt maturities are some of the consequences of asymmetric information. Drawing on the corporate finance literature, Razin, Sadka, and Yuen (1998) note that the composition of flows to emerging markets suggests a pecking order-foreign direct investment, followed by debt, and finally, equity - an outcome that is consistent with asymmetry in information between domestic and foreign investors.

${ }^{4}$ In his comment on the Ghosh and Wolf (2000) paper, Savastano questions whether physical distance is a proxy for higher transactions costs. The extent of informational asymmetry in is as likely - or more so- to reflect the nature of institutions governing financial transactions and while distance from the world's main money centers may proxy in some cases for the lack of institutional development, that need not necessarily be the case. Moreover, in the $1990 \mathrm{~s}$, some crisis countries were quite close to major money centers and were yet plagued by informational asymmetries.

${ }^{5}$ Obstfeld and Rogoff (2000) argue that transportation costs in goods can account for segmentation of international financial markets. 
Thus, there is both theoretical and empirical basis for expecting informational frictions to play an important role in determining the supply of capital to developing countries. The contributions discussed above invoke information asymmetries to explain the geographical distribution of international capital flows, the mobility of capital, or the composition of capital. In contrast, we take an approach that, at the same time, identifies supply and demand functions for international capital and allows for a time-varying characterization of information asymmetries. Time variation in information asymmetries has been found to be important also in developed country financial markets (Korajczyk, Lucas, and McDonald, 1992).

\section{Modeling Disequilibrium in Capital Flows: Econometric IsSues}

A capital crunch may be said to occur when there is excess demand for capital inflows to the economy and the short side of the market-in this case the supply of capital flowdetermines the amount of capital inflow. If we denote the demand for and supply of capital flow, respectively, at time $t$ by $\mathrm{C}_{\mathrm{t}}^{\mathrm{d}}$ and $\mathrm{C}_{\mathrm{t}}^{\mathrm{s}}$, and the actual amount of capital inflow by $\mathrm{C}_{\mathrm{t}}$, then the notion that the short side of the market dominates may be formally expressed by the minimum condition:

$$
C_{t}=\operatorname{Min}\left(C_{t}^{d}, C_{t}^{s}\right)
$$

Suppose we have vectors of variables that are deemed to determine $C_{t}^{d}$ and $C_{t}^{s}$ through relationships of the form:

$$
\begin{aligned}
& C_{t}^{d}=\beta^{\prime} X_{t}^{d}+u_{t}^{d} \\
& C_{t}^{s}=\gamma^{\prime} X_{t}^{s}+u_{t}^{s}
\end{aligned}
$$

where $u_{t}^{d}$ and $u_{t}^{s}$ denote white noise disturbance, $\beta$ and $\gamma$ are parameter vectors, and it is understood that the vectors of explanatory variables may share some elements in common. The econometric problem is then to estimate the parameter vectors in the system (1)-(3) and to determine whether the market is on the supply or demand curve at any given point in time-or, more specifically, to determine whether there was a capital crunch at any point time such that

$$
C_{t}=\operatorname{Min}\left(C_{t}^{d}, C_{t}^{s}\right)=C_{t}^{s}
$$

Often, in empirical disequilibrium modeling, some indication of which side of the market dominates is inferred from an examination of the price of the good or service whose behavior is being modeled, under the assumption that a rising price indicates excess demand (so that supply is the short side) and, conversely, a falling price represents excess supply (so that demand is the short side). The sample of data can be separated according to whether the 
supply or the demand schedule is in force and the model can be estimated in a fairly straightforward manner (Fair and Jaffee, 1972).

This approach is not satisfactory in an analysis of capital flows, however, since, as discussed above, interest rates may be unresponsive to excess supply or demand because of the adverse selection problem in credit markets and the possibility of credit rationing (Stiglitz and Weiss, 1981). Accordingly, we apply methods originally developed by Kiefer (1980) and Maddala (1983) for estimating a disequilibrium model with unknown sample separation (see also Amemiya, 1974 and Maddala and Nelson, 1974). With these methods, we proceed on the basis that we cannot say for certain whether an observation belongs to the demand or the supply schedule, but we can infer the probability of it belonging to one or the other.

More specifically, denote by $\theta_{\mathrm{t}}$ the probability of a capital crunch occurring at any given point in time-i.e. the probability that any given observation belongs to the supply curve given the observed amount of capital inflow, which we denote $\mathrm{C}_{\mathrm{t}}$ :

$$
\theta_{t}=\operatorname{Pr}\left(C_{t}^{s}<C_{t}^{d} \mid C_{t}\right)
$$

where $\mathrm{C}_{t}^{\mathrm{s}}$ and $\mathrm{C}_{\mathrm{t}}^{\mathrm{d}}$ denote the supply and demand for credit respectively.

Assuming that $\mathrm{u}_{\mathrm{t}}^{\mathrm{d}}$ and $\mathrm{u}_{\mathrm{t}}^{\mathrm{s}}$ are independently and normally distributed, the likelihood function may be written (Kiefer, 1980; Maddala, 1983):

$$
L_{t}=\prod_{t=1}^{T}\left[\begin{array}{c}
\left(1 / \sigma^{s}\right) \varphi\left[\left(C_{t}-\gamma^{\prime} X_{t}^{s}\right) / \sigma^{s}\right]\left[1-\Phi\left[\left(C_{t}-\beta^{\prime} X_{t}^{d}\right) / \sigma^{d}\right]\right] \\
+\left(1 / \sigma^{d}\right) \varphi\left[\left(C_{t}-\beta^{\prime} X_{t}^{d}\right) / \sigma^{d}\right]\left[1-\Phi\left[\left(C_{t}-\gamma^{\prime} X_{t}^{s}\right) / \sigma^{s}\right]\right]
\end{array}\right]
$$

where $\varphi$ and $\Phi$ are the standard normal density and distribution functions respectively. Intuitively, this form of the likelihood function weights the likelihoods that would prevail in each regime by the probability of being in that regime given the data. The model can then be estimated by standard optimization methods.

We can also compute the implied probability of a capital crunch at any point in time, $\theta_{t}$ as defined in (5), as:

$\theta_{t}=$

$\frac{\left(1 / \sigma^{s}\right) \varphi\left[\left(C_{t}-\gamma^{\prime} X_{t}^{s}\right) / \sigma^{s}\right]\left[1-\Phi\left[\left(C_{t}-\beta^{\prime} X_{t}^{d}\right) / \sigma^{d}\right]\right]}{\left(1 / \sigma^{s}\right) \varphi\left[\left(C_{t}-\gamma^{\prime} X_{t}^{s}\right) / \sigma^{s}\right]\left[1-\Phi\left[\left(C_{t}-\beta^{\prime} X_{t}^{d}\right) / \sigma^{d}\right]\right]+\left(1 / \sigma^{d}\right) \varphi\left[\left(C_{t}-\beta^{\prime} X_{t}^{d}\right) / \sigma^{d}\right]\left[1-\Phi\left[\left(C_{t}-\gamma^{\prime} X_{t}^{s}\right) / \sigma^{s}\right]\right]}$

which is just the likelihood of being on the supply curve normalized by the total likelihood. 


\section{EMPIRICAL IMPLEMENTATION}

In this paper we are concerned with modeling supply and demand functions for so-called 'capital market flows'- that is to say, bond, equity and syndicated loan flows - to a group of emerging markets, namely Brazil, Mexico, Korea, and Thailand over the period from the beginning of 1990 through to mid $2000 .^{6}$ Data on bond, equity, and bank flows for this period were added together to form an overall capital market flow series for each country, with monthly observations on the individual bond, equity and syndicated loan flow series obtained from Euromoney's Bondware and Loanware. These series represent gross capital flows. ${ }^{7}$

Before the model can be implemented empirically, however, it is clearly necessary to specify what variables are to be included on the right-hand-side of each equation. As noted above, the literature has tended to distinguish between global 'push' and country-specific 'pull' factors in the determination of portfolio flows (see e.g., Chuhan, Claessens, and Mamingi, 1998; Taylor and Sarno, 1997). The approach taken here differs from the 'push-pull' approach in that both global and country-specific factors may determine the supply of capital flows (although factors determining the demand for capital flows will in general be countryspecific).

On the supply side, the global 'push' factors we considered included variables such as the level of both short-term and long-term US interest rates (represented by the yield on 1-year Treasury bills and the yield on 10-year government bonds), the US high yield spread (the spread charged for less than investment grade_or 'junk' - bonds over the US Treasury bill rate), a measure of industrialized country economic activity (proxied by an index of US industrial production), and a measure of the cost of capital (the Emerging Markets Bond Index (EMBI) of spreads over the US risk-free rate). In addition, we also considered the effect of country-specific factors that may influence the supply of portfolio flows, such as country credit rating, liquidity position, domestic short-term interest rates, and stock market returns. Although credit rating may not be a good predictor of financial crisis (Goldstein,

${ }^{6}$ We do not include foreign direct investment (FDI) flows in our analysis for two reasons. First, as shown by Sarno and Taylor (1999a), the time series properties of FDI flows are quite different from those of capital market flows. Second, in keeping with these findings, studies have also found that FDI flows tend to be driven by longer-term considerations such as market size, infrastructure availability, education, and so on (see e.g., Mody and Srinivasan, 1998).

${ }^{7}$ The resulting series were transformed to logarithmic form prior to the analysis. Where a zero appeared for an observation, this was replaced with unity so that its logarithm became zero. Since the series are in millions of dollars, replacing zero dollars with one dollar will not materially affect the empirical analysis. 
Kaminsky, and Reinhart, 2000; Reinhart, 2001), one would nevertheless expect it to influence the supply of capital to a particular country. The ratio of reserves to short-term debt (debt repayable within the coming year) was also included in the supply function on the supposition that a decrease in its value would raise concerns about a country's liquidity and hence its ability to honor debts that are imminently due, making investing in that particular country less attractive.

On the demand side we considered: (a) indicators of economic activity, such as the level and rate of change of the consumer price index, the level of the domestic stock market index, the level and rate of growth of domestic industrial production, and the reserves to imports ratio; (b) a measure of the availability of alternative forms of finance: the ratio of domestic credit to GDP; and (c) cost of capital measures such as the domestic short-term interest rate and the movements in the domestic stock market index; and also the international cost of capital as proxied by the EMBI. ${ }^{8}$

In the event, as we report below, not all variables proved significant and a more parsimonious set of variables was sufficient to track the supply and demand for capital flows. Thus, expected default risk in the US, proxied by the 'high-yield' or 'junk' bond spread (the premium over risk-free bonds for less than investment grade credit), turned out to be important in explaining supply of capital to the four emerging markets. Default risk in the United States could be correlated with emerging market default risk; moreover, Gertler and Lown (2000) argue that a rise in the high-yield spread predicts slowdown in real economic activity (through the 'financial accelerator' mechanism) and the anticipated slowdown could rein in international capital flows. Once high-yield spreads and US growth rates were included, US interest rates did not play a statistically significant role and were dropped from the analysis. The level and change of domestic stock market indices were influential, the former in generating demand and the latter in attracting supply, but domestic interest rates did not prove to be a statistically significant influence.

Note that reserves appear both in the supply equation (where they are normalized by shortterm debt) and in the demand equation (where they are normalized by imports). ${ }^{9}$ The ratio of reserves to short-term debt measures a country's liquidity and has become a prominent indicator of a country's vulnerability to capital flow reversals, especially since mid-1997, following the triggering of the Asian crisis. While a country's credit rating should, in

${ }^{8}$ We do not consider the effect of capital controls on the supply and demand for capital inflows. In part, this is due to Montiel and Reinhart's (1999) finding that capital controls do not influence the volume of capital flows. In part, also, available measures of capital flows are at an annual frequency and tend to be characterized in terms of discrete shifts.

${ }^{9}$ Since the reserve variables only enter with a lag into our empirical equations, there is no simultaneity bias induced in our estimation because of any effects capital flows may have on the current level of reserves. 
principle, incorporate its liquidity position, in practice, ratings do not appear to have systematically accounted for such short-term vulnerability. The independent impact of the ratio of reserves to short-term debt is confirmed in recent analysis. For example, Eichengreen and Mody (2000) find that a higher reserves to short-term debt ratio increases the probability that a country will contract a new syndicated loan in international markets and also lowers the spread charged on that loan. Thus, in effect, a higher reserves to short-term debt ratio shifts the supply curve outward. In contrast, the reserves to imports ratio serves to signal demand. While it is the case that a decline in reserves relative to imports makes a country more vulnerable to short-term risks, it also increases the demand for external resources to finance ongoing imports. Once again, Eichengreen and Mody (2000) find support for the proposition that a fall in reserves relative to imports increases the probability of contracting an international syndicated loan.

A full listing of the variables used in the analysis and their sources is given in the data appendix. The constructed database consisted of monthly observations for the period 1990:01-2000:06. In our empirical work, we also allowed for some dynamic effects in the data by entering these variables in the current period and with lags.

\section{Empirical Results: The Probability of Crunch}

The results of maximum likelihood estimation applied to the models for Brazil, Mexico, Korea and Thailand, using monthly data for the period 1990:01-2000:6, are given in Table 1, where we report only our final parsimonious equations, i.e. the estimated equations where variables which appeared with coefficients insignificantly different from zero ${ }^{10}$ have been deleted. The estimated coefficients for the supply and demand functions are in each case significantly different from zero and the signs of the estimated coefficients accord well with our economic priors.

\section{A. Estimates of Supply and Demand Functions}

A number of the results shown in Table 1 are particularly worth highlighting. Superior credit rating (and, hence, lower default risk) increases the supply of capital, as 0 expected. The reserves to short-term debt ratio exercises an independent influence on supply: a higher ratio is seen to have a strongly positive and significant impact in all countries. The prospects of higher returns (more rapid rise in the domestic stock market over the past 12 months and higher available spreads) also increase the supply of capital. The 'financial accelerator' mechanism--and hence a particular manifestation of asymmetric information-appears to operate through two different channels: US growth and the US high-yield or junk bond spreads. A higher growth rate of US industrial production has a significant positive effect on the supply of capital. Since US industrial growth proxies well

${ }^{10}$ We use a nominal significance level of five percent throughout. 
for the cyclical behavior of global industrial growth, ${ }^{11}$ the evidence suggests that capital flows are strongly procyclical. This evidence is consistent with the 'financial accelerator' model, which predicts that credit flows will be positive correlated with real activity (Bernanke, Gertler, and Gilchrist 1999). In turn, that model depends, as discussed above, on the assumption of asymmetry in information between borrowers and lenders. Higher growth reduces the impact of asymmetry because it raises the value of the borrower's collateral. In the context of cross-country capital flows, the collateral is presumably raised as export prospects improve in a higher global growth environment.

As with the realized growth rates, anticipated changes in output also have significant effects on the supply of capital. We find that higher US high-yield spreads are associated with reduced supply of capital to emerging markets. While the coefficients are highly significant for all four countries, they are especially large for the Latin American countries. A rise in these high-yield spreads, arising from an increase in expected default rates, acts as an indicator of anticipated economic woes and proves to be a strong signal of economic slowdown (Gertler and Lown, 2000). This signaling of an economic slowdown is particularly strong, Gertler and Lown (2000) argue, because a financial accelerator is at work: higher spreads indicate worsening financial balance sheets, which in turn redices access to external sources of finance and amplify the extent of the economic downturn.

On the demand side, Table 1 also presents evidence that stronger domestic economic activity, as reflected in the rate of growth of industrial production and the level of the domestic stock market, increases a developing economy's appetite for international capital. These effects are more pronounced in the East Asian countries. Higher reserves in relation to imports lower the demand for capital, as discussed above, though this again is the case especially in the two East Asian countries. Thus, a higher level of imports, all else equal, increases the demand for capital, a finding that is consistent with that of Hajivassiliou (1986). ${ }^{12}$ Moreover, a higher level of international reserves in relation to imports has the effect of reducing the demand for international capital and, in this sense, reserves are a substitute for international capital; however, as discussed above, higher reserves in relation to short-term debt signal a greater ability to repay and so are complementary to international capital flows. ${ }^{13}$ Finally, a rise in the cost of capital (i.e., a rise in the spreads as proxied by the EMBI) reduces demand for capital.

${ }^{11}$ Agénor, McDermott, and Prasad (2000) find that 'business cycle fluctuations in developing countries tend to be correlated with business cycle fluctuations in industrialized countries.'

${ }^{12}$ Eaton and Gersowitz (1981) find that larger imports are associated with a reduced demand for capital and consider that finding to be "anomalous."

${ }^{13}$ Eaton and Gersowitz (1980) conclude that reserves are a substitute for international capital. But the statistical significance of their result is weak and may reflect, as we find here, the dual role that reserves play: while they help finance current transactions and so are a substitute to private capital, they give confidence to investors and help attract capital. 
Table 1. Estimated Supply and Demand Functions for International Capital Flows

\begin{tabular}{|c|c|c|c|c|}
\hline & \multicolumn{3}{|c|}{ A. Supply Function } & \multirow[b]{2}{*}{ Thailand } \\
\hline & Brazil & Mexico & Korea & \\
\hline (Credit Rating) $)_{\mathrm{t}}$ & $\begin{array}{c}0.195 \\
(0.071)\end{array}$ & $\begin{array}{c}0.144 \\
(0.032)\end{array}$ & $\begin{array}{c}0.145 \\
(0.035)\end{array}$ & $\begin{array}{c}0.132 \\
(0.051)\end{array}$ \\
\hline$\Delta_{12}(\log \text { of domestic stock market index })_{t}$ & $\begin{array}{l}0.131 \\
(0.041)\end{array}$ & & & \\
\hline$\Delta_{12}(\log \text { of domestic stock market index })_{t-1}$ & $\begin{array}{l}0.016 \\
(0.003)\end{array}$ & $\begin{array}{c}0.157 \\
(0.041)\end{array}$ & $\begin{array}{c}0.174 \\
(0.053)\end{array}$ & $\begin{array}{l}0.183 \\
(0.053)\end{array}$ \\
\hline (Log of Emerging market spreads) & $\begin{array}{c}1.274 \\
(0.482)\end{array}$ & & & \\
\hline (Log of Emerging market spreads) $)_{\mid-1}$ & $\begin{array}{c}0.245 \\
(0.111)\end{array}$ & $\begin{array}{c}1.202 \\
(0.224)\end{array}$ & $\begin{array}{c}1.211 \\
(0.424)\end{array}$ & $\begin{array}{c}1.584 \\
(0.643)\end{array}$ \\
\hline$\Delta(\text { US High Yield Spread })_{t}$ & $\begin{array}{l}-0.916 \\
(0.443)\end{array}$ & $\begin{array}{l}-0.794 \\
(0.284)\end{array}$ & $\begin{array}{l}-0.197 \\
(0.044)\end{array}$ & $\begin{array}{l}-0.079 \\
(0.041)\end{array}$ \\
\hline$\Delta(\text { US High Yield Spread })_{\mathrm{t}-1}$ & $\begin{array}{l}-0.384 \\
(0.131)\end{array}$ & & & \\
\hline (Reserves/Short-term debt) ${ }_{t-1}$ & $\begin{array}{c}0.736 \\
(0.321)\end{array}$ & $\begin{array}{c}0.449 \\
(0.183)\end{array}$ & $\begin{array}{c}0.435 \\
(0.185)\end{array}$ & $\begin{array}{c}0.542 \\
(0.217)\end{array}$ \\
\hline$\Delta(\text { US Industrial Production })_{t-1}$ & $\begin{array}{c}0.331 \\
(0.113)\end{array}$ & $\begin{array}{c}0.415 \\
(0.124)\end{array}$ & $\begin{array}{c}0.356 \\
(0.126)\end{array}$ & $\begin{array}{c}0.254 \\
(0.102)\end{array}$ \\
\hline Constant & $\begin{array}{c}6.411 \\
(2.012)\end{array}$ & $\begin{array}{c}7.874 \\
(2.001)\end{array}$ & $\begin{array}{c}3.252 \\
(2.002)\end{array}$ & $\begin{array}{c}4.085 \\
(2.002)\end{array}$ \\
\hline$\sigma^{8}$ & $\begin{array}{c}1.306 \\
(0.350)\end{array}$ & $\begin{array}{c}1.114 \\
(0.333)\end{array}$ & $\begin{array}{c}1.254 \\
(0.225)\end{array}$ & $\begin{array}{c}1.156 \\
(0.331)\end{array}$ \\
\hline & & emand & tion & \\
\hline & Brazil & Mexico & Korea & Thailand \\
\hline (Log of domestic stock market index $)_{t}$ & $\begin{array}{c}0.379 \\
(0.302)\end{array}$ & $\begin{array}{c}0.429 \\
(0.122)\end{array}$ & $\begin{array}{c}0.778 \\
(0.302)\end{array}$ & $\begin{array}{c}1.079 \\
(0.302)\end{array}$ \\
\hline$\Delta$ (industrial production $)_{t}$ & $\begin{array}{c}0.464 \\
(0.142)\end{array}$ & $\begin{array}{c}0.384 \\
(0.142)\end{array}$ & $\begin{array}{c}0.952 \\
(0.242)\end{array}$ & $\begin{array}{c}0.887 \\
(0.142)\end{array}$ \\
\hline (Reserves/Import) $)_{t-1}$ & $\begin{array}{l}-0.100 \\
(0.424)\end{array}$ & $\begin{array}{l}-0.118 \\
(0.424)\end{array}$ & $\begin{array}{l}-0.209 \\
(0.084)\end{array}$ & $\begin{array}{l}-0.232 \\
(0.084)\end{array}$ \\
\hline (Log of Emerging market spreads) & $\begin{array}{l}-0.983 \\
(0.484)\end{array}$ & $\begin{array}{l}-1.221 \\
(0.484)\end{array}$ & $\begin{array}{l}-1.017 \\
(0.284)\end{array}$ & $\begin{array}{l}-0.936 \\
(0.414)\end{array}$ \\
\hline Constant & $\begin{array}{c}13.495 \\
(2.002)\end{array}$ & $\begin{array}{l}-5.041 \\
(2.002)\end{array}$ & $\begin{array}{l}-8.874 \\
(2.002)\end{array}$ & $\begin{array}{l}-0.634 \\
(2.002)\end{array}$ \\
\hline$\sigma^{d}$ & $\begin{array}{c}1.412 \\
(0.240)\end{array}$ & $\begin{array}{c}0.762 \\
(0.221)\end{array}$ & $\begin{array}{c}1.202 \\
(0.392)\end{array}$ & $\begin{array}{c}1.127 \\
(0.314)\end{array}$ \\
\hline
\end{tabular}

Notes : Estimation is by maximum likelihood, as described in the text. Figures in parentheses are estimated standard errors. $\sigma^{s}$ and $\sigma^{d}$ denote the estimated standard errors of the disturbances in the supply and demand functions respectively $\left(u^{s}\right.$ and $\left.u^{d}\right)$.

$\Delta$ and $\Delta_{12}$ denote, respectively the first- and twelfth-difference operators, defined such that: $\Delta \mathrm{x}_{\mathrm{t}} \equiv \mathrm{x}_{\mathrm{t}}-\mathrm{x}_{\mathrm{t}-1}$ and $\Delta_{12} \mathrm{x}_{\mathrm{t}} \equiv \mathrm{x}_{\mathrm{t}}-\mathrm{x}_{\mathrm{t}-12}$. 


\section{B. Probability of a Capital Crunch}

Using these estimated coefficients, Figures 1-4 show the fitted supply and demand functions for each of the four countries over the estimation period, together with the probability $\left(\theta_{t}\right.$ in the discussion above) that demand exceeds supply at each point in time.

Consider first the Latin American countries (Figures 1-2). The model clearly picks up the 1994 and 1998 crises, with the probability of a capital crunch at or around 100 percent in each of these periods. For both countries, the model suggests that the balance of probability is that they were both still experiencing a capital crunch during the 1999-2000 period, with the probability for Brazil bumping above 50 percent and that for Mexico around the $80-90$ percent level. Note, however, for both the Latin American countries, the early period of the decade, was one of a relatively low value of $\theta_{t}$. In Mexico, for example, $\theta_{t}$ fell below 0.4 in the early part of 1994, suggesting a short span in the first half of 1994 when supply exceeded demand. However, supply fell below demand some months before the onset of the crisis in December 1994, as if investors were already backing off, and the severe constraint in supply peaked only in mid-1995. In Brazil also, after relatively benign capital market conditions in late 1993 and early 1994, there was some choppiness in access from mid-1994, with the constraint peaking, as in Mexico, in mid-1995.

The 1997 East Asian crisis is clearly captured in the results for Korea and Thailand, as is the 1998 crisis associated with Russia and the collapse of Long Term Credit Management (Figures 3-4). However, Thailand in particular shows a lower probability of a capital crunch in the 1999-2000 period. Indeed, the model generates a probability of crunch of around 50 percent, suggesting a clearing market. For both Korea and Thailand, the period before the July 1997 crisis is characterized mainly by an apparently clearing market: although $\theta_{t}$ falls or rises for brief periods, it remains close to 0.5 during this period. There may have been exuberance in international capital markets at times during the 1990s, but it did not imply that supply greatly exceeded demand at any given time. Thus, during periods when the supply curve moved to the right, it moved to fulfill demand at a lower cost of funds, so that investor exuberance was reflected in sharply lower costs of funds in the 1996 and early 1997 periods. From a peak of 2100 (spread in basis points over a dollar risk-free rate) in the first quarter of 1995, following the Mexican crisis, the average spreads fell to 990 basis points in the third quarter of 1997 before climbing back up as the various subsequent crises unfolded.

Overall, therefore, for the 1999-2000 period, the models suggest a high probability of capital rationing in the Latin American countries and lower probabilities of capital rationing in the East Asian countries. Note our earlier finding that Latin American supply also falls more sharply with a rise in US high-yield spreads. This evidence of greater rationing of Latin American economies is in line with that of Eichengreen, Hale, and Mody (2001) who show that East Asian issuers are better able to time the issuance of their bonds than is the case for Latin American issuers. In other words, because East Asian issuers face less of a supply 
constraint, they can choose the timing at which they enter the market to take advantage of favorable terms and conditions. ${ }^{14}$

\section{Domestic Factors Associated with a Capital Crunch}

While the models allow for a large number of factors to drive these results, it is worth examining which of the underlying factors is particularly influential. In this connection it is also worth pointing out the differing behavior of reserves between these Latin American and East Asian countries (Figures 1-4, panel c). The ratios of reserves to short-term debt and reserves to imports have risen strongly in Korea since 1997, as shown in Figure 3, panel c. This will have contributed to increasing the supply of capital and reducing the demand, thus tending to alleviate capital rationing and the probability of a capital crunch. The same is also true of the ratio of reserves to short-term debt in Thailand, although the reserves to imports ratio appears to have stagnated and even slightly worsened after rising sharply.

The behavior of the reserves ratios in the Latin American countries is quite different, however. In general, the ratios are much lower and, in particular, the collapse in the reserves to imports ratio in Mexico in the 1993-94 period coincides with a marked increase-indeed a step change - in the probability of a capital crunch from which it never seems to have recovered. In Brazil, the reserves to short-term debt ratio is clearly strongly correlated with the supply of capital and (inversely) with the probability of a capital crunch. This is perhaps particularly evident in contributing to the rise in the probability of a capital crunch during the 1999-2000 period.

The behavior of reserves, while an important determinant of both the supply of and the demand for capital, clearly only tells part of the story, however, as this analysis is based on multivariate modeling. For example, the slightly increased probability of a capital crunch at the very end of the estimation period for Korea mirrors a rise in demand for capital, in large measure due to a recovery in economic activity reflected in an upturn in both output growth and stock prices towards the middle of 2000. On the other hand, the fairly flat level of economic activity in Thailand, reflected in both output and stock price movements, during the early part of 2000 translates into flat capital inflow demand, so that the Thai economy does not appear capital rationed at that point.

\footnotetext{
${ }^{14}$ Kletzer (1984) also argues that countries in Latin America, with their lower savings and investment rates, are likely to be more credit rationed than East Asian economies. This conclusion follows from his analysis that high savings and investment rates are likely to signal more productive uses of foreign capital.
} 


\section{Conclusions}

In this paper we have examined the determinants of capital flows to a set of emerging markets over a turbulent period, namely from the beginning of 1990 through to mid 2000. We used an explicitly disequilibrium econometric framework in which supply and demand are not necessarily equal and the actual amount of the flow is determined by the 'short side' of the market. The econometric results were highly encouraging in that a parsimonious model fits the data across the four countries. The coefficient estimates have signs that accord with our economic priors, are typically similar in magnitude across countries, and are statistically well determined.

The results suggest that in the early part of the $1990 \mathrm{~s}$, as a fresh wave of capital began to flow into emerging markets, demand for such capital was at times lower than supply. However, the four countries considered adapted quite quickly to this new regime of international capital flows and for much of the period, either supply and demand were in balance or demand was constrained by supply. This appears to have been the case even in the 'exuberant' period of 1996 and the first half of 1997, when the spreads charged for emerging market debt fell sharply: our results imply that as supply curves shifted to the right, they did so along the downward sloping demand curve. Moreover, we were also able to apply the estimated models to gauge the degree of likelihood of instances of 'international capital crunch'-where capital flows are curtailed because of supply-side rationing. The results again accord with our economic intuition.

Our results also highlight the effects of asymmetric information, evident in protracted rationing for some countries, in rationing during crisis periods for all the countries considered, and in the strong procyclicality of supply of capital flows. In contrast to the earlier literature, which invoked informational asymmetries to explain cross-sectional variations in the extent and composition of international capital flows, we show that there may not only be some long-standing differences between countries in this respect but also that significant changes may be induced in the supply of capital within a country over time when information is asymmetrically held.

Further research might usefully extend this analysis to a more disaggregated level to identify further the causes and implications of asymmetric information by types of flows (equity, loans, and bonds) and identity of borrowers (private or public). While some of that analysis could be carried out within the framework of aggregate flows adopted in this paper, data on individual transactions may become more relevant for other extensions. Other possible extensions include the possibility of examining contagion effects through including cross linkages between supply equations for different countries and to study the demand for international reserves in supply and demand constrained regimes (as suggested by Eaton and Gersowitz 1980). 
Figure 1a. Brazil: Capital Flow Demand and Supply

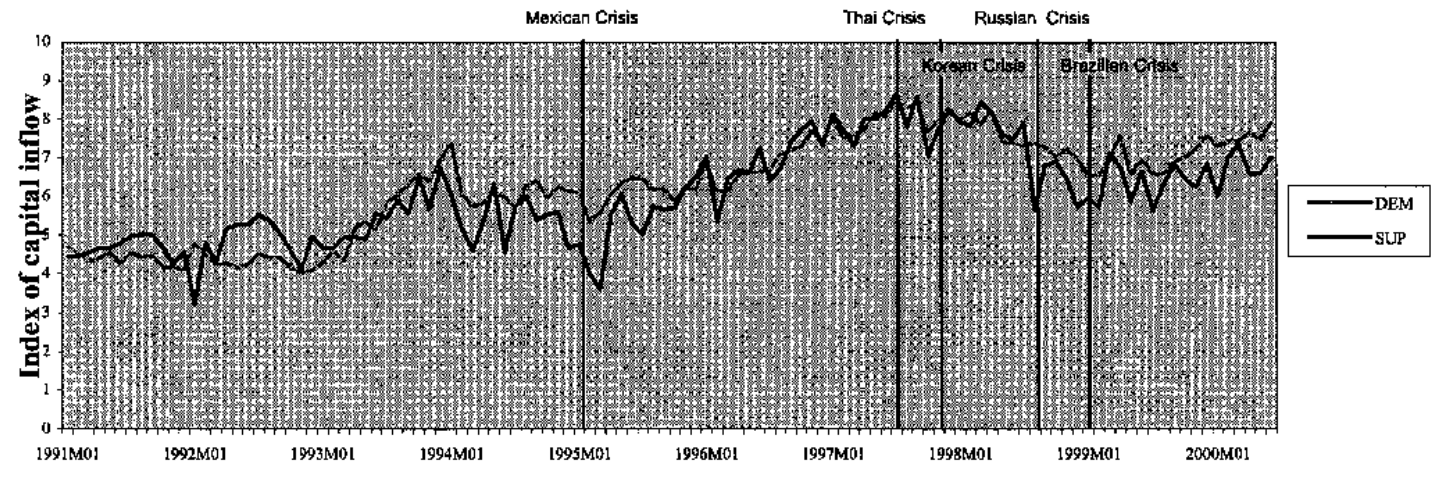

Figure 1b. Brazil: Probability of Crunch

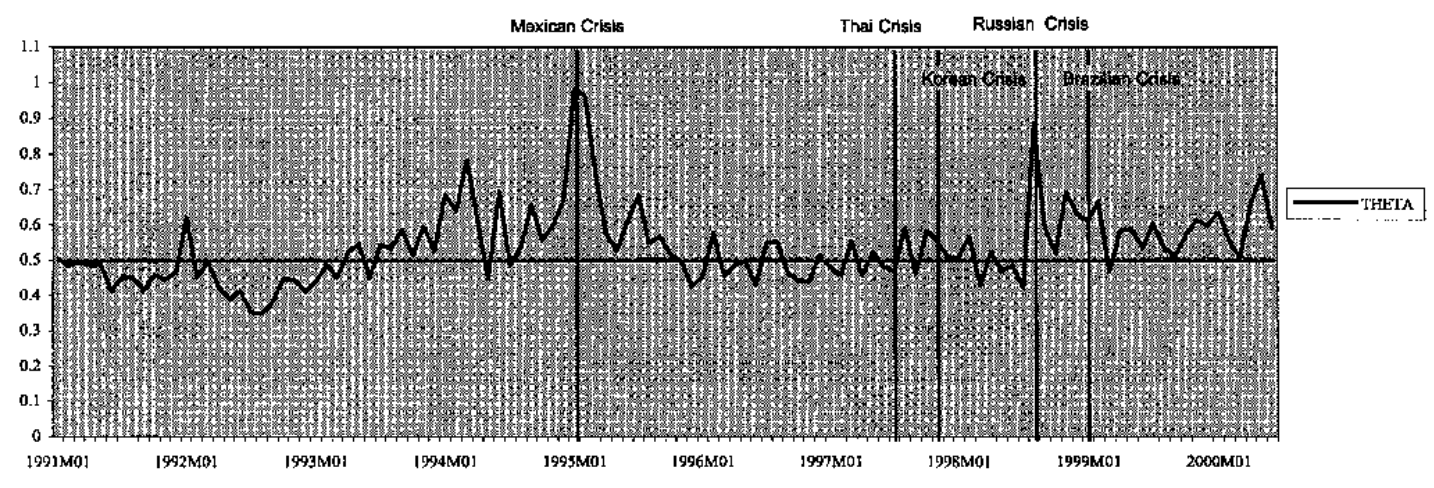

Figure 1c. Brazil: Reserves/Imports and Reserves/Short-Term Debt Mexican Crisis Thai Crisis Russian Crisis

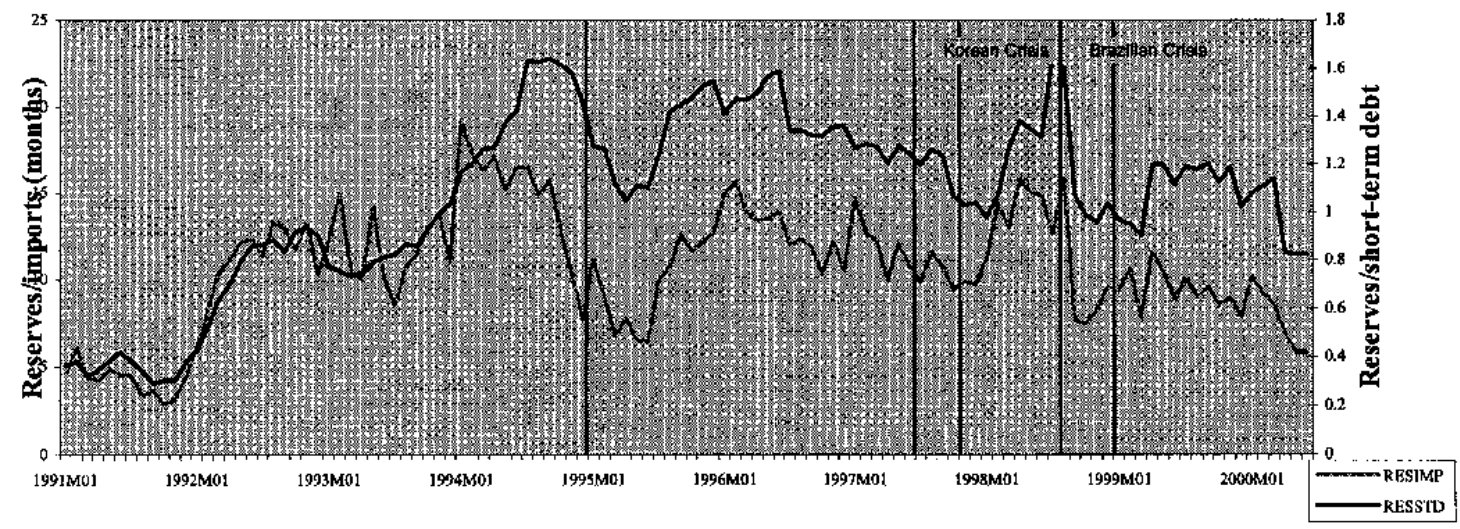


Figure 2a. Mexico: Capital Flow Demand and Supply

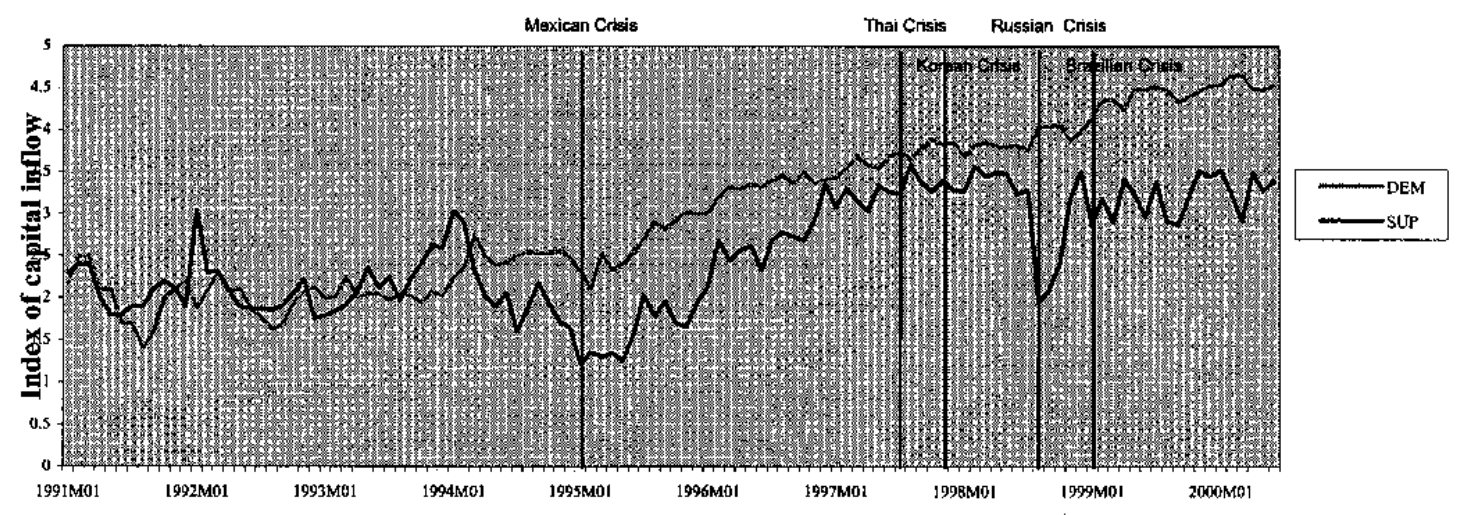

Figure 2b. Mexico: Probability of Crunch

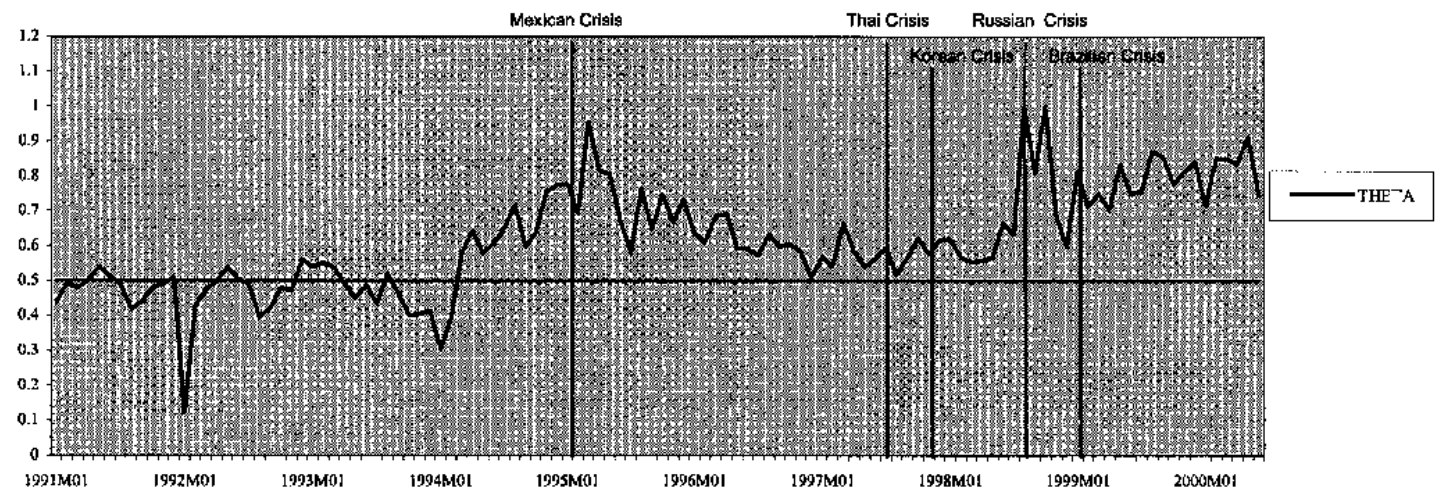

Figure 2c. Mexico: Reserves/Imports and Reserves/Short-Term Debt

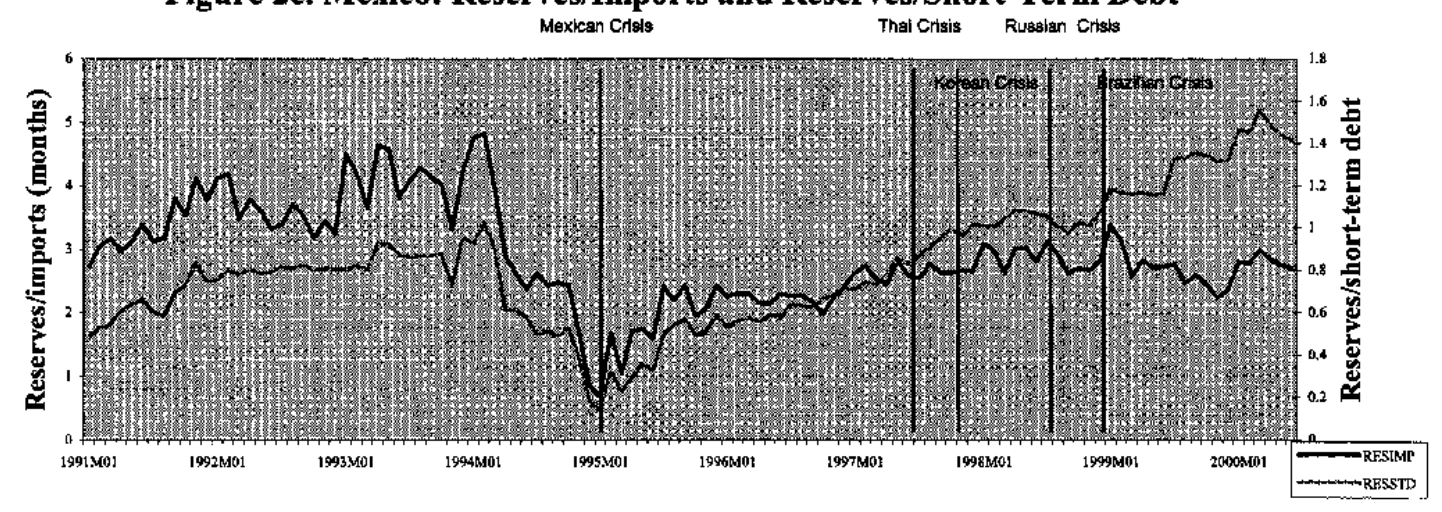


Figure 3a. Korea: Capital Flow Demand and Supply

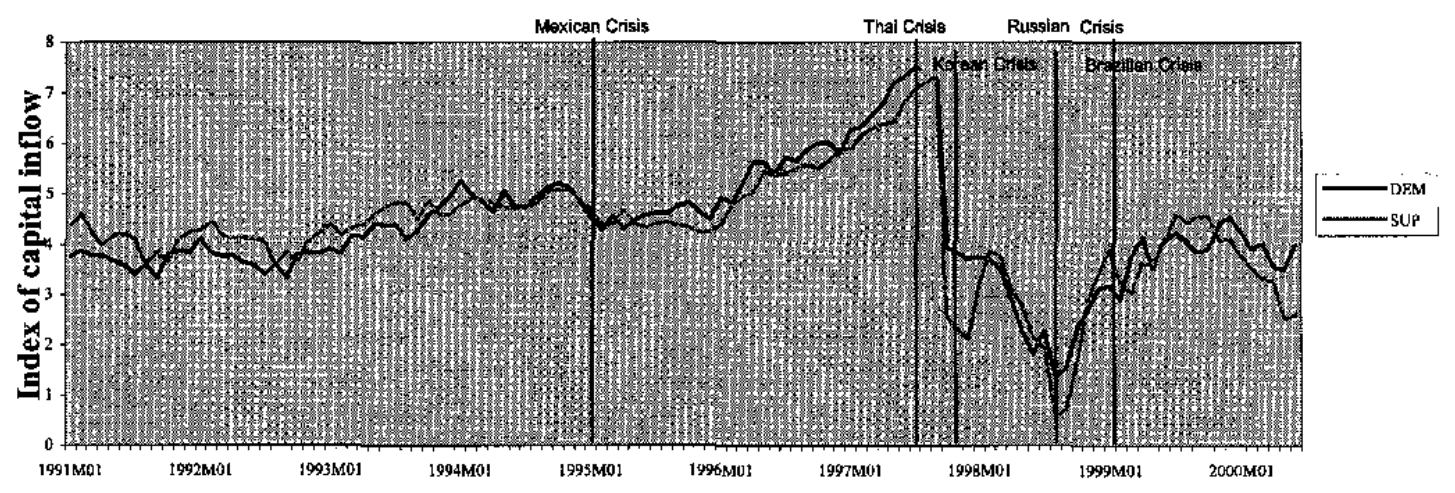

Figure 3b. Korea: Probability of Crunch

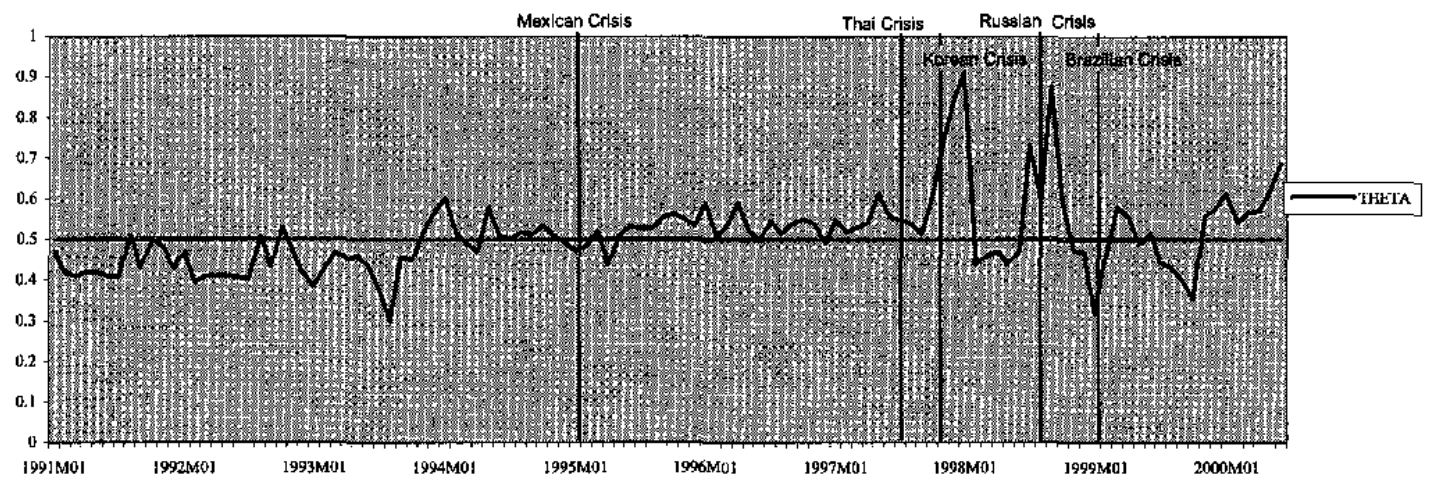

Figure 3c. Korea: Reserves/Imports and Reserves/Short-Term Debt

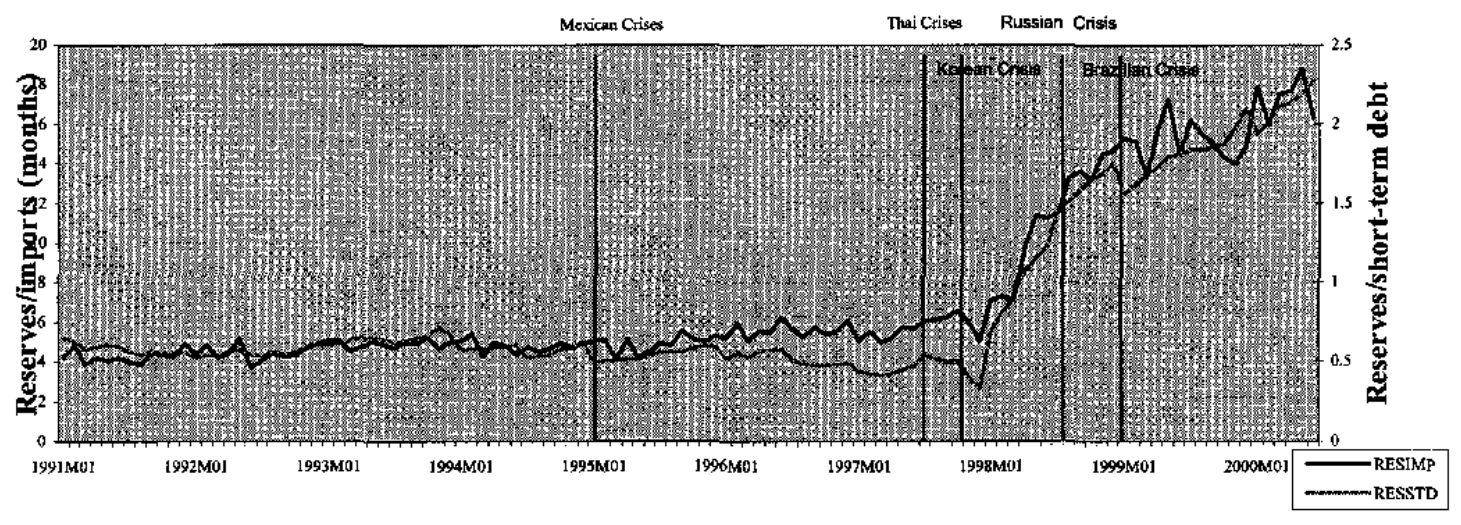


Figure 4a. Thailand: Capital Flow Demand and Supply

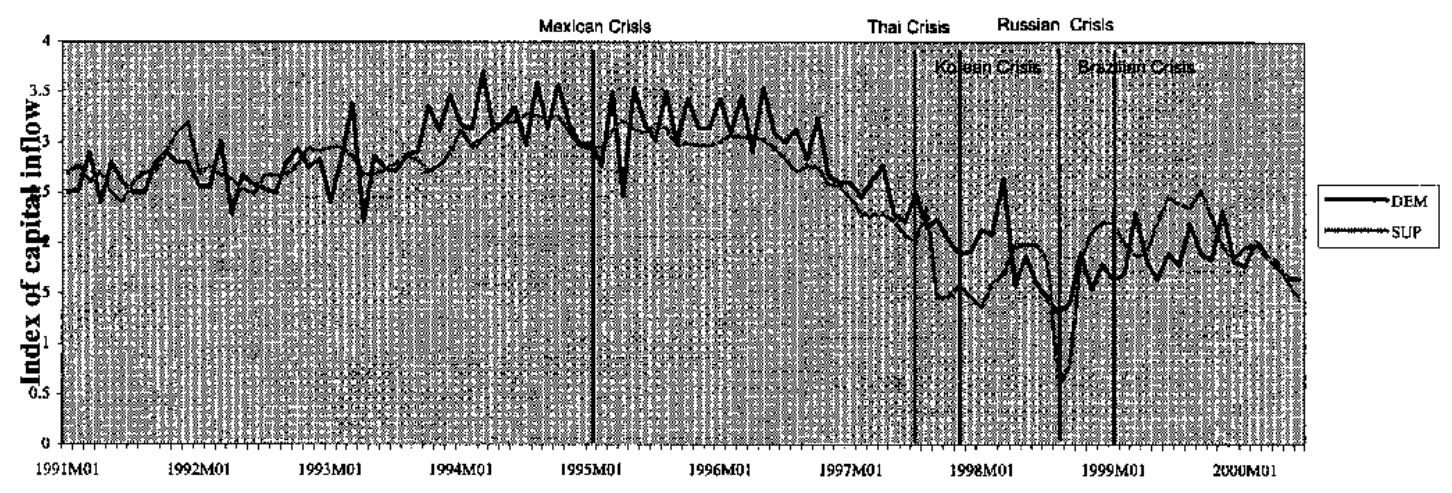

Figure 4b. Thailand: Probability of Crunch

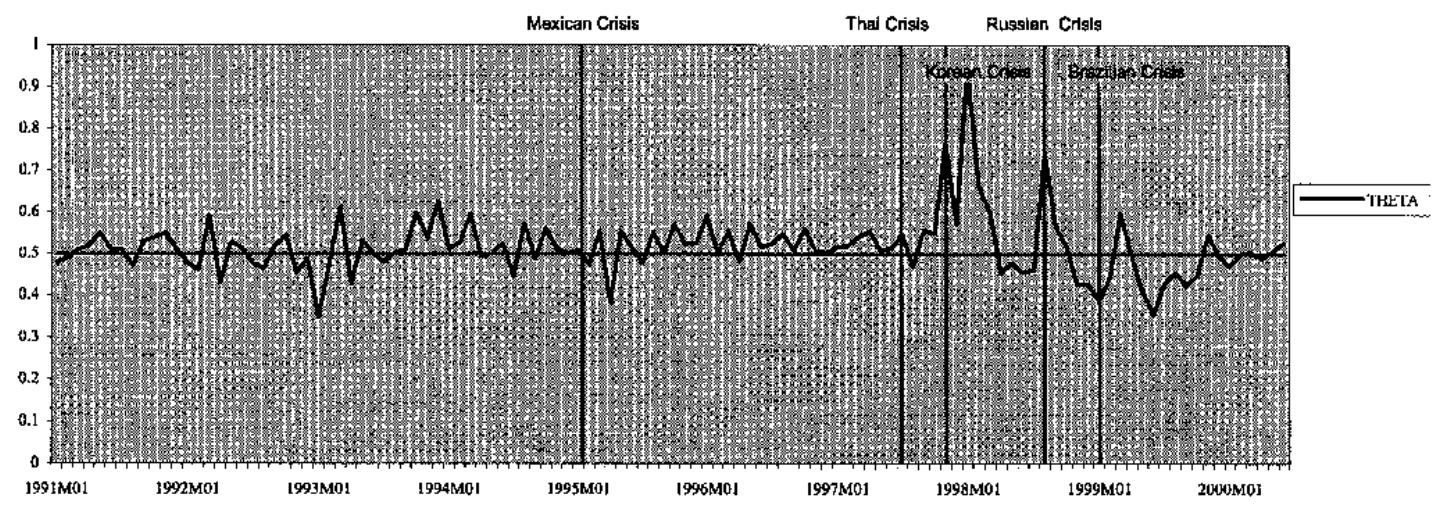

Figure 4c. Thailand: Reserves/Imports and Reserves/Short-Term Debt

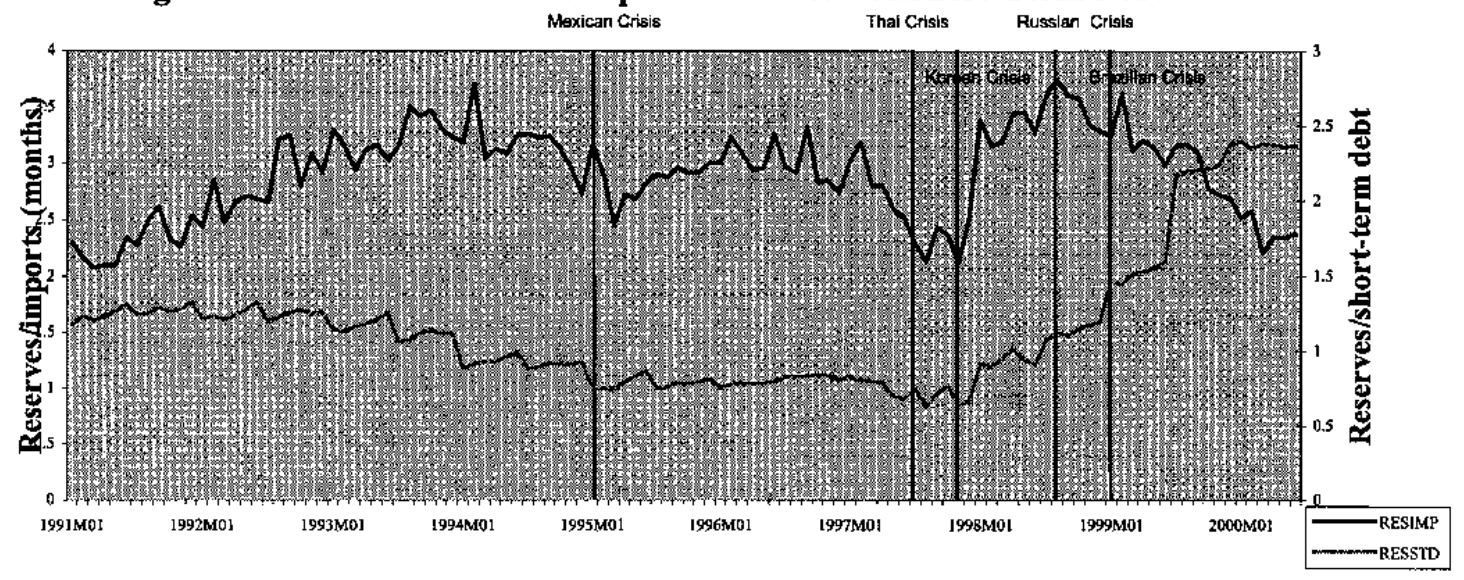




\section{REFERENCES}

Agénor, P.-R. (1998), "The Surge in Capital Flows: Analysis of 'Pull' and 'Push' Factors," International Journal of Finance and Economics, 3, pp. 39-57.

Agénor, P.-R., and P. Montiel (1999), Development Macroeconomics, second edition. Princeton NJ: Princeton University Press.

Agénor, P.-R., C. John McDermott, and Eswar Prasad (2000), "Macroeconomic Fluctuations in Developing Countries: Some Stylized Facts," The World Bank Economic Review 14(2): 251-85.

Amemiya, T. (1974), "A Note on the Fair and Jaffee Model," Econometrica, 42, pp 759-62.

Bernanke, B., M. Gertler, and S. Gilchrist (1999), "The Financial Accelerator in a Quantitative Business Cycle Framework," in John Taylor and Michael Woodford (eds.) Handbook of Macroeconomics, Amsterdam, New York: North-Holland, Elsevier.

Caballero, Ricardo and Arvind Krishnamurthy (2001), "A Vertical Analysis of Crises and Central Bank Intervention," mimeo, Massachusetts Institute of Technology, Cambridge MA.

Calvo, G., L. Leiderman, and C.M. Reinhart (1996), "Inflows of Capital to Developing Countries in the 1990s," Journal of Economic Perspectives, 10, pp. 123-39.

Calvo, G., and E. Mendoza (2000), "Rational Contagion and the Globalization of Securities Markets,"Journal of International Economics, 51, pp. 79-103.

Calvo, G. and C.M. Reinhart (1999), "When Capital Inflows Come to a Sudden Stop: Consequences and Policy Options," in P. Kenen and A. Swoboda, Key Issues in Reform of the International Monetary and Financial System, (Washington DC: International Monetary Fund, 2000).

Chuhan, P., S. Claessens, and M. Mamingi (1998), "Equity and Bond Flows to Asia and Latin America," Journal of Development Economics, 55, pp. 439-63.

Claessens, S., M.P. Dooley, and A. Warner (1995), "Portfolio Capital Flows: Hot or Cold?" World Bank Economic Review, 9, pp. 153-74.

Ding, W., I. Domac, and G. Ferri (1998), "Is There a Credit Crunch in East Asia?" Asia Pacific Journal of Economics and Business, 2, pp. 4-32.

Dornbusch, R., Y.C. Park, and S. Claessens (2000), "Contagion: Understanding How it Spreads," World Bank Research Observer, 15, pp. 177-97. 
Eaton, Jonathan and Mark Gersowitz (1980), "LDC Participation in International Financial Markets: Debt and Reserves," Journal of Development Economics 7, pp. 3-21.

Eaton, Jonathan and Mark Gersowitz (1981), "Debt with Potential Repudiation: Theoretical and Empirical Analysis,"Review of Economic Studies 48, pp. 289-309.

Eichengreen, B. and A. Mody (2000), "Lending Booms, Reserves, and the Sustainability of Short-Term Debt: Inferences from the Pricing of Syndicated Loans," Journal of Development Economics, 63, pp. 5-44.

Eichengreen, B., G. Hale, and A. Mody (2001), "Flight to quality: investor risk tolerance and the spread of emerging market crises," in Stijn Claessens and Kristin Forbes, eds., International Financial Contagion, Kluwer Academic Publishers.

Fair, R. and D. Jaffee (1972), "Methods of Estimation for Markets in Disequilibrium," conometrica, 40, pp 497-514.

Gertler, Mark and Kenneth Rogoff (1990), "North-South Lending and Endogenous Domestic Capital Market Inefficiencies," Journal of Monetary Economics 26: 245-266.

Gertler, Mark and Cara Lown (2000), "The Information in the High-Yield Bond Spread for the Business Cycle: Evidence and Some Implications," National Bureau of Economic Research Working Paper 7549, Cambridge MA.

Ghosh, S.W. (1999), "Korea in the Aftermath of the Crisis: Credit Crunch or Lack of Demand?" World Bank, mimeo.

Ghosh, Swati and Holgar Wolf (2000), "Is there a Curse of Location? Spatial Determinants of Capital Flows to Emerging Markets," in Sebastian Edwards (ed.) Capital Flows and the Emerging Economies: Theory Evidence, and Controversies, The University of Chicago Press, Chicago.

Goldstein, M., G.L. Kaminsky, and C. Reinhart (2000), Assessing Financial Vulnerability: An Early Warning System for Emerging Markets. Washington DC: Institute for International Economics.

Gordon, Richard and A. Lans Bovenberg (1996), "Why is Capital So Immobile Internationally? Possible Explanations and Implications for Capital Income Taxation," American Economic Review 86(5), pp. 1057-1075.

Hajvassiliou, Vassilis (1987), "The External Debt Problems of LDC's: An Econometric Model Based on Panel Data," Journal of Econometrics 36, pp. 205-230.

International Monetary Fund (2000), International Capital Markets: Developments, Prospects, and Policy Issues. Washington DC: International Monetary Fund. 
Kiefer, N.M. (1980), “A Note on Regime Classification in Disequilibrium Models," Review of Economic Studies, 47, pp. 637-9.

Kletzer, Kenneth M. (1984), “Asymmetries of Information and LDC Borrowing with Sovereign Risk," Economic Journal 94(374): 287-307.

Korajczyk, Robert A., Deborah J. Lucas, and Robert L. McDonald (1992), "Equity Issues with Time-Varying Asymmetric Information," Journal of Financial and Quantitative Analysis 27 (3): 397-417.

Maddala, G.S. (1983), Limited Dependent and Qualitative Variables in Econometrics. Cambridge and New York: Cambridge University Press.

Maddala, G.S. and F.D. Nelson (1974), "Maximum Likelihood Methods for Models of Markets in Disequilibrium," Econometrica, 42, pp 1013-30.

Mankiw, N. Gregory (1986), “The Allocation of Credit and Financial Collapse,” Quarterly Journal of Economics pp 455-470.

Mody, A, and K. Srinivasan (1998) "US and Japanese Investors: Do They March to the Same Tune?" Canadian Journal of Economics, 31, pp. 778-99.

Mody, A., M.P. Taylor, and J.Y. Kim. (2001a) "Modeling Economic Fundamentals for Forecasting Capital Flows to Emerging Markets," International Journal of Finance and Economics 6(3): 201-216.

Mody, A., M.P. Taylor and J.Y. Kim (2001b), "Forecasting Capital Flows to Emerging Markets: A Kalman Filtering Approach," forthcoming Applied Financial Economics.

Montiel, Peter and Carmen Reinhart (1999), "Do Capital Controls and Macroeconomic Policies Influence the Volume and Composition of Capital Flows? Evidence from the 1990s," Journal of International Money and Finance, 18, pp. 619-635.

Obstfeld, Maurice and Kenneth Rogoff (200), "The Six Major Puzzles in International Macroeconomics: Is there a common cause?" National Bureau of Economic Research Working Paper 7777, Cambridge MA.

Pazarbasiouglou, C. (1997), "A Credit Crunch? Finland in the Aftermath of the Banking Crisis," International Monetary Fund Staff Papers, 44, pp 315-27.

Portes, Richard and Helene Rey (2001), "The Determinants of Cross-Border Equity Flows," mimeo, Princeton University. www.princeton.edu/ hrey.

Razin, A., E. Sadka, and C.W. Yuen (1998), "A Pecking Order of Capital Inflows and International Tax Principles," Journal of International Economics 44: 45-68. 
Reinhart, C.M. and V.R. Reinhart (2001), "Some Lessons for Policy Makers Dealing with the Mixed Blessing of Capital Inflows," in M. Kahler (ed.) Capital Flows and Financial Crises (New York: Council on Foreign Relations), pp. 93-127.

Reinhart, C.M. (2001), "Sovereign Credit Ratings Before and After Financial Crises," mimeo, Department of Economics, University of Maryland.

Sarno, L. and M.P. Taylor (1999a), "Hot Money, Accounting Labels, and the Persistence of Capital Flows to Developing Countries: An Empirical Investigation," Journal of Development Economics, 59, pp. 337-64.

Sarno, L. and M.P. Taylor (1999b), "Moral Hazard, Asset Price Bubbles, Capital Flows and the East Asian Crisis: The First Tests," Journal of International Money and Finance, 18, pp. 637-57.

Savastano, Miguel (2000), "Comment on Ghosh and Wolf," in Sebastian Edwards (ed.) Capital Flows and the Emerging Economies: Theory Evidence, and Controversies, The University of Chicago Press, Chicago.

Stiglitz, J. and A. Weiss (1981), "Credit Rationing in Markets with Imperfect Information," American Economic Review, 71, pp. 393-410.

Taylor, M.P., and L. Sarno (1997), "Capital Flows to Developing Countries: Long- and Short-Term Determinants," World Bank Economic Review, 11, pp. 451-71.

Woo, W.T., J. Sachs, and K. Schwab (eds.) (2000), The Asian Financial Crisis : Lessons for a Resilient Asia. Cambridge and London: MrT Press.

World Bank (1997), The Road to Financial Integration: Private Capital Flows to Developing Countries. Washington DC: World Bank. 